\section{s \\ Spectacle, Rhetoric and Power. The Triumphal Entry of Prince Philip of Spain into Antwerp*}

(Stijn Bussels, Ámsterdam-Nueva York:

Rodopi, 20I2)

por

TANIA VANESSA ALVAREZ PORTUGAL ${ }^{* *}$

En el contexto de las celebraciones regias, los arcos triunfales fueron un elemento central en los reinos hispanos bajo los Habsburgo. Ya fueran en honor al rey o a virreyes, constituían el elemento arquitectónico que concentraba principalmente las solicitudes del reino y las cualidades del personaje homenajeado. En el ámbito festivo, esta arquitectura solía ser efímera, de tal manera que sus relaciones, descripciones y en algunos casos grabados, son los únicos testimonios por los que, al día de hoy, podemos acercarnos a ella.

Así, esta situación es la que da pie a diversos cuestionamientos que el investigador actual de los arcos de triunfo debe tener en cuenta al momento de establecer el ángulo a partir del cual se acercará a su objeto de estudio, ya sea que lo considere como arquitectura efímera o como literatura festiva por ejemplo, puesto que los arcos de triunfo son un impor-

\footnotetext{
* Texto recibido el 4 de agosto de 20I4, aceptado el 30 de enero de 2015 .

** Becaria del doctorado en Historia del Arte de la Facultad de Filosofía y Letras de la UNAM.
}

tante elemento dentro del ceremonial de las festividades regias - como entronamiento o entradas a ciudades bajo el dominio de la corona- usualmente conformadas también por una ceremonia de jura, torneos, comedias y corridas de toros, entre otras.

En los horizontes de la monarquía hispana y sus festejos en reinos hispanohablantes, contamos con los vastos y destacados estudios de Víctor Mínguez, Fernando Rodríguez de la Flor, Inmaculada Rodríguez Moya, Francesc Massip y David García Cueto en el caso de España y los virreinatos; Francisco de la Maza y Joaquín Velázquez de León aportan información sobre diversos arcos y entradas triunfales en la Nueva España, cuyos análisis se ven complementados por los más recientes estudios de José Miguel Morales Folguera, José Pascual Buxó y Judith Farre; mientras Ricardo Estabridis Cárdenas, por su parte, se enfoca en el estudio de los festejos en el virreinato del Perú; sin embargo, salvo el análisis iconográfico y de la maquinaria teatral presentada por Massip respecto a la llegada de Carlos de Gante a Brujas, en I5II, los festejos llevados a cabo en el norte de Europa no habían recibido una atención tan especial como la que les dedica Stijn Bussels.

Stijn Bussels desarrolló su tesis de doctorado para presentar en Spectacle, Rhetoric and Power. The Triumphal Entry of Prince Philip of Spain into Antwerp una visión integral del excelso festejo llevado a cabo en Amberes en 1549, por medio del cual se ratificaba la lealtad del ducado de Bravante con la corona imperial, en este caso, con el heredero del rey Carlos, el príncipe Felipe. El autor cuenta con diversas fuentes que le permiten hacer un estudio bastante amplio y profundo sobre la intención, la forma y el significado de los aparatos festivos, en el cual presenta su aná- 
lisis y sus consideraciones que, aunque provenientes de distantes coordenadas, resultan de mucha ayuda a los interesados en el tema.

Bussels, muy consciente del contexto intelectual dentro del cual se desarrolló su objeto de estudio, no descuida las corrientes humanistas del siglo XVI en el norte de Europa, la importancia de la educación retórica y las nociones del teatro de la memoria en boga. De esta manera, decide aproximarse a las imágenes de los arcos de triunfo - a las cuales tiene acceso por medio de los grabados realizados por Pieter Coecke van Aelstde la mano del reporte oficial de los festejos escrito por el organizador en jefe, Cornelius Grapheus. Para él, el hilo conductor del discurso es la retórica, así, encuentra que la dispositio iconográfica y textual presentan una similar jerarquía de motivos. Sostiene que la gestualidad escultórica es cercana a la actio de la oratoria con prescripciones humanistas y, con base en la comparación de entradas triunfales del mismo cortejo en Lille y en Génova, propone una iconografía frecuente en los festejos de los Habsburgo.

Un análisis que tome como punto central la retórica puede brindar luz no sólo sobre las disposiciones del discurso, sino también respecto de la conformación del gusto y la afinidad que el grupo creativo tenía con ciertas corrientes de pensamiento. La comparación de entradas triunfales de las mismas personas a diferentes ciudades y reinos es un ejercicio conveniente para delinear diferencias en el discurso que cada entidad dirigía al rey -las cuales refieren el tipo de gobierno que cada una tenía- así como el tipo de negociaciones que por este medio se establecían.

Respecto a los preparativos de la celebración, Bussels cuenta con la relación del organizador en jefe, el Spectaculorum in Susceptione
Phillipi de Cornelius Grapheus, ${ }^{\mathrm{I}}$ quien incluso menciona atractivos que por la premura de la llegada del rey y del príncipe, no pudieron estar listos. Pocas veces se cuenta con los elementos para poder hablar de la organización de las celebraciones reales: una ordenanza, recibos en archivos de ayuntamientos, y tal vez alguna carta entre gremios y con suerte algún contrato; sin embargo todos estos materiales pueden ayudar a formar una idea sobre los pareceres en la preparación de la fiesta.

Una gran problemática en las investigaciones de las fiestas y de lo efímero radica en el estudio de la recepción que pudo haber tenido, no simplemente por parte del principal destinatario, sino de la ciudad anfitriona y participante, debido mayormente a la escasez de fuentes al respecto. En este punto, el autor compagina y compara narraciones - de la crónica oficial de Grapheus, de El felicissimo viaje d'el muy Alto y muy Poderoso Principe Don Phelippe, escrito por el noble español Juan Cristóbal Calvete de Estrella, ${ }^{2}$ relator del viaje del príncipe Felipe, y del mercader italiano Ludovico Guicciardini autor de la Descrittione di tutti i Paesi Bassi-y aunque no puede extenderse en impresiones públicas de todo el festejo, logra reconstruir algunas posturas en situaciones específicas, como la actitud general respecto al gasto que se estimaba excesivo; asimismo, rescata las impresiones que los organizadores o los miembros de la corte tuvieron sobre las respuestas de la gente.

I. Spectaculorum in Susceptione Phillipi Hisp. Divi Caroli. V. Caes. F. An. M. D. XLIX. Antverpiae Aeditorum, Mirificus Apparatus.

2. El felicissimo viaje d'el muy Alto y muy Poderoso Principe Don Phelippe hijo d'el Emperador Don Carlos Quinto Maximo desde España a sus tierras de la baxa Alemaña. 
La obra de Bussels propone análisis transversales entre diversas prácticas contemporáneas, tiende lazos entre intelectuales directa o indirectamente relacionados con la organización de los festejos y la impresión de las relaciones - así como entre diversos testigos que legaron sus observaciones-, al tiempo que explica la historia de prácticas culturales esenciales para la comprensión del fenómeno de la fiesta y del recibimiento triunfal; ofrece datos y sugiere reflexiones de gran utilidad para el estudioso de la retórica y la iconografía del poder, del arte efímero y de las fiestas reales.

\section{s \\ Federico Sánchez Fogarty \\ Un visionario de su tiempo*}

\author{
México: Consejo Nacional para la Cultura y las Artes- \\ Instituto Nacional de Bellas Artes/Casa Estudio \\ Diego Rivera y Frida Kahlo, 2014 \\ por \\ FABIOLA HERNÁNDEZ**
}

El Museo Casa Estudio Diego Rivera albergó en 2014 la exposición "Federico Sánchez Fogarty: un visionario de su tiempo". El catá-

\footnotetext{
* Texto recibido el 5 de diciembre de 2014 , aceptado el 30 de enero de 2015 .

** Doctoranda en Historia del Arte en la Facultad de Filosofía y Letras de la UNAM.
}

logo de la muestra, motivo de esta reseńa, se integra a una serie de trabajos que previamente han estudiado la labor y relevancia de la publicidad de Cementos Tolteca, dirigida por Federico Sánchez Fogarty, para la historia del arte, la fotografía y la arquitectura en México durante las primeras décadas del siglo xx. ${ }^{\mathrm{I}}$ En este sentido, debe celebrarse que en el catálogo de esta exposición, se reúnen por primera vez óleos, portadas de revistas, fotografías y documentos que conformaron tanto la publicidad como la colección del publicista.

El catálogo está integrado por seis ensayos que presentan una revisión de la trayectoria de Federico Sánchez Fogarty, el panorama de las artes visuales en México durante la década de I930, el estado de la industria de la construcción en la ciudad de México en la segunda década posrevolucionaria, reflexiones en torno a la arquitectura de esos ańos, una reseña de la visita del director de cine Sergei M. Eisenstein a México, y las repercu-

I. James Oles, "La nueva fotografía y Cementos Tolteca: Una alianza utópica”, en Mexicana: fotografía moderna en México, I923-1940, catálogo de la exposición (Valencia: Generalitat Valenciana, 1998), I39-I52; Enrique X. de Anda Alanís, La arquitectura de la Revolución mexicana: corrientes y estilos en la década de los veinte (México: Universidad Nacional Autónoma de México-Instituto de Investigaciones Estéticas, 2008); Deborah Dorotinsky, "Federico Sánchez Fogarty: el concreto y la fotografía de arquitectura en I933", en Seminario Internacional Arquitectura y Ciudad (México: Universidad Autónoma Metropolitana, 20IO), 20I-2I7; Rubén Gallo, Mexican Modernity: The Avant-Garde and the Technological Revolution (Cambridge, Mass.: Massachusetts Institute of Technology, 2005); Georg Leidenberger, "Tres revistas de arquitectura: portavoces de la modernidad, I923-I950", Anales del Instituto de Investigaciones Estéticas XXXIV, núm. IOI (20I2): I09-I38. 